\title{
ANALISIS EFISIENSI PEMASARAN BENIH IKAN LELE DI DESA SITUMANDALA KECAMATAN RANCAH KABUPATEN CIAMIS
}

\section{ANALYSIS OF THE EFFICIENCY OF MARKETING CATFISH SEEDS IN THE VILLAGE OF SITUMANDALA, RANCAH SUB-DISTRICT, CIAMIS DISTRICT}

\author{
AHMAD MUKLISIN ${ }^{1 *}$, DINI ROCHDIANI ${ }^{2}$, DAN BUDI SETIA ${ }^{1}$ \\ ${ }^{1}$ Fakultas Pertanian, Universitas Galuh Ciamis \\ ${ }^{2}$ Fakultas Pertanian Universitas Padjajaran \\ *E-mail : muklisinahmad62@gmail.com
}

\begin{abstract}
ABSTRAK
Penelitian ini bertujan untuk mengetahui : (1) Saluran pemasaran benih ikan lele dari petani sampai konsumen, (2) Besarnya marjin pemasaran benih ikan lele. (3) Besarnya bagian harga yang diterima petani benih ikan lele, dan (4) Efisien tidaknya pemasaran benih ikan lele di Desa Situmandala Kecamatan Rancah Kabupaten Ciamis. Penelitian ini dilaksanakan di Desa Situmandala Kecamatan Rancah Kabupaten Ciamis dengan menggunakan metode survey dengan jumlah responden 14 orang petani benih ikan lele yang ditentukan secara disengaja berdasarkan pertimbangan tertentu ( purposive sampling ) dan pedagang perantara diambil dengan menggunakan metode penelusuran (snowball sampling). Pedagang perantara yang diambil dalam penelitian ini yaitu 6 orang yang terdiri dari 2 orang pedagang pengepul, 1 orang pedagang besar dan 3 orang pedagang pengecer. Data yang di peroleh dianalisis secara deskriptif. Hasil penelitian menjelaskan, bahwa terdapat dua saluran pemasaran benih ikan lele di Desa Situmandala yaitu,
\end{abstract}

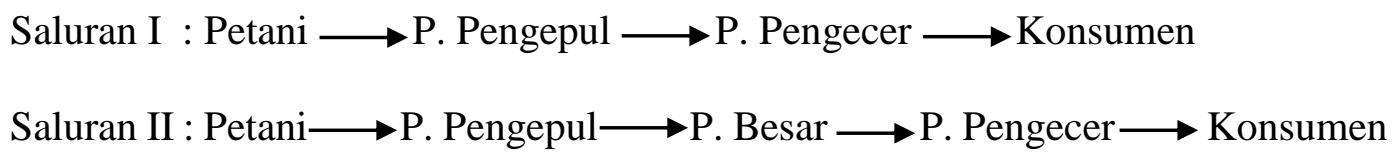

Besarnya marjin pemasaran benih ikan lele pada saluran pemasaran I adalah pada pedagang pengepul yaitu Rp. 80 per ekor dan pedagang pengecer Rp. 55 per ekor. Sedangkan pada saluran pemasaran II pedagang pengepul yaitu Rp. 20 per ekor, pedagang besar Rp. 70 per ekor, dan pada pedagang pengecer Rp. 50 per ekor. Persentase bagian harga yang diterima petani pada saluran pemasaran I adalah 52,631 persen dan pada saluran pemasaran II adalah 51,724 persen dari bagian harga yang di bayarkan oleh konsumen.Berdasarkan hasil penelitian, seluruh saluran pemasaran benih ikan lele yang ada di Desa Situmandala sudah efisien, namun saluran pemasaran I merupakan saluran pemasaran yang lebih efisien dibandingkan dengan saluran pemasaran II. Namun saluran pemasaran II ini yang menjadi pilihan utama pembudidaya.

Kata Kunci: Saluran Pemasaran, Marjin Pemasaran, Farmer's Share, Efisiensi Pemasaran

\section{ABSTRACT}

This study aims to determine: (1) The marketing channel for catfish seeds from farmers to consumers, (2) The amount of marketing margin for catfish seeds. (3) The size of the portion of the price received by catfish seed farmers, and (4) Efficient or not the marketing of catfish seeds in Situmandala Village, Rancah District, Ciamis Regency. This research was conducted in Situmandala Village, Rancah Subdistrict, Ciamis Regency by using a survey method with 14 respondents of catfish seed farmers who were determined deliberately based on certain considerations (purposive sampling) and the intermediary traders were taken using the snowball sampling method. The intermediary traders taken in this study were 6 people consisting of 2 collectors, 1 wholesaler and 3 retailers. The data obtained were analyzed descriptively. The results of the study explained that there were two marketing channels for catfish seeds in Situmandala Village, namely, 
Channel I: Farmers $\longrightarrow$ P. Collectors $\longrightarrow$ P. Retailers $\longrightarrow$ Consumers

Channel II: Farmers $\longrightarrow$ P. Collectors $\longrightarrow$ P. Besar $\longrightarrow$ P. Retailers. $\longrightarrow$ Consumers

The marketing margin for catfish seeds in marketing channel I is for collectors, namely Rp. 80 per head and retailers $R p .55$ per head. Meanwhile, in the second marketing channel, the collectors are Rp. 20 per head, wholesaler Rp. 70 per head, and at retailers Rp. 50 per head. The percentage share of the price received by farmers in marketing channel I is 52.631 percent and marketing channel II is 51.724 percent of the share of the price paid by consumers. Based on the results of the research, all of the catfish seed marketing channels in Situmandala Village are efficient, but marketing channel I is a more efficient marketing channel than the channel marketing II. However, this second marketing channel is the main choice for cultivators.

Keywords: Marketing Channels, Marketing Margins, Farmer's Share, Marketing Efficiency.

\section{PENDAHULUAN}

Pembangunan sektor perikanan adalah suatu proses perubahan dan pembaharuan yang berencana menuju tatanan masyarakat, khususnya masyarakat perikanan yang lebih baik. Perikanan mempunyai peranan yang cukup penting, terutama dikaitkan dengan upaya peningkatan kualitas dan kuantitas produk perikanan, menghasilkan protein hewani dalam rangka memenuhi kebutuhan pangan gizi, meningkatkan ekspor, menyediakan bahan baku industri, memperluas lapangan kerja dan kesempatan berusaha, serta mendukung pembangunan wilayah dan tetap memperhatikan kelestarian dan fungsi lingkungan hidup. (Hanafiah, 2014).

Salah satu komoditi perikanan yang memiliki prospek cukup baik untuk dikembangkan sebagai ikan konsumsi adalah Ikan Lele ( Clarias sp.). Konsumsi ikan lele telah menjadi suatu kebutuhan yang harus dijamin ketersediannya. Hal ini disebabkan tingginya permintaan ikan lele baik untuk kebutuhan konsumsi rumah tangga maupun kebutuhan usaha kuliner seperti lamongan.

Menurut Kementrian Perikanan Dan Kelautan (2013), Pertumbuhan sektor perikanan dan kelautan berasal dari produksi perikanan tangkap maupun perikanan budidaya. Selama ini kegiatan budidaya ikan air tawar lebih banyak di lakukan oleh Pembudidaya Ikan Lele kecil yang belum mempunyai akses terhadap manajemen usaha, pasar dan permodalan. Dalam rangka pemerataan pembangunan, Kegiatan budidaya perikanan dapat dijadikan alternatif komoditi di bidang agroindustri yang memiliki prospek yang besar apabila dikembangkan. Perikanan di Indonesia dapat dibagi menjadi tiga jenis perikanan yaitu: Perikanan Air Laut, Perikanan Air Payau dan Perikanan Air Tawar. Perikanan Air Laut adalah perikanan yang diusahakan di wilayah 
perairan laut lepas; Perikanan Air Payau adalah perikanan yang diusahakan dalam bentuk tambak di muara sungai ataupun daerah yang dekat dengan air laut, sedangkan Perikanan Air Tawar adalah perikanan yang diusahakan di kolam dan perairan umum ataupun sawah.

Ikan lele mempunyai banyak keunggulan dibanding jenis ikan lainnya. selain pertumbuhannya yang cepat, ikan lele juga memiliki kandungan gizi yang tinggi, sehingga permintaan akan ikan lele selalu mengalami peningkatan. Hal ini dapat diketahui bahwa ikan lele tidak hanya unuk konsumsi rumah tangga dan memenuhi permintaan pedagang pecel lele, tetapi telah menjadi salah satu menu utama rumah makan.

Budidaya ikan lele mencakup dua kegiatan yaitu pembenihan dan pembesaran. pembenihan dilakukan untuk mendapatkan benih ikan lele ukuran tertentu ( $5 \mathrm{~cm}$ sampai $7 \mathrm{~cm}$ ). Sedangkan pembesaran ikan lele merupakan kegiatan menghasilkan ikn lele ukuran konsumsi yaitu pada saat mencapai berat 100 gram (Suyanto, 1999). Kegiatan pembesaran tidak dapat berjalan jika tidak ada kegiatan pembenihan. karena benih merupakan sala satu faktor yang sangat berpengaruh terhadap keberhasilan budidaya ikan , terutama dalam penelitian ini yaitu khusus pada kegiatan pembenihan ikan lele.

Menurut Dinas Peternakan dan Perikanan Kabupaten Ciamis (2019), hasil produksi ikan lele di Kabupaten Ciamis pada Tahun 2019 adalah sebagai berikut :

Tabel 1. Data Produksi Ikan Lele di Kabupaten Ciamis Tahun 2020

\begin{tabular}{llc}
\hline No & \multicolumn{1}{c}{ Kecamatan } & Produksi (Ton) \\
\hline 1 & Banjarsari & 401.91 \\
2 & Banjaranyar & 361.89 \\
3 & Lakbok & 185.36 \\
4 & Pamarican & 871.73 \\
5 & Cidolog & 546.78 \\
6 & Cimaragas & 231.4 \\
7 & Cijengjing & 918.72 \\
8 & Cisaga & 934.84 \\
9 & Tambaksari & 309.3 \\
$\mathbf{1 0}$ & Rancah & $\mathbf{8 1 9 . 5 1}$ \\
11 & Rajadesa & 982.04 \\
12 & Sukadana & 284.67 \\
13 & Ciamis & 628.6 \\
14 & Cikoneng & 711.95 \\
15 & Cihaurbeuti & 767.82 \\
16 & Sadananya & 907.19 \\
17 & Cipaku & 1144.47 \\
18 & Jatinagara & 345.03 \\
19 & Panawangan & 773.74 \\
20 & Kawali & 855.71 \\
21 & Panjalu & 572.1 \\
22 & Panumbanga & 1192.08 \\
23 & Sindangkasih & 525.22 \\
24 & Baregbeg & 651.91 \\
25 & Lumbung & 489.06 \\
26 & Purwadadi & 762.98 \\
27 & Sukamantri & 416.76 \\
\hline & Total Produksi & $\mathbf{1 7 . 5 9 6 . 9 7}$ \\
\hline & Ser & Dinas Peterakan \\
\hline
\end{tabular}

Sumber : Dinas Peternakan dan Perikanan Kabupaten Ciamis, 2019.

Dilihat dari data di atas Kecamatan Rancah merupakan salah satu sentra produksi ikan lele yang memiliki prospek yang cukup baik untuk di kembangkan. Hal ini dapat dilihat dari total produksi ikan lele 
pada tahun 2019 yang mencapai 819.51 (ton). Sedangkan untuk memenuhi produksi budidaya ikan lele diperlukan juga benih ikan lele. Salah satu sentra pembenihan ikan lele di Kecamatan Rancah berada di Desa Situmandala. Benih ikan lele dari Desa Situmandala dipasarkan di tingkat lokal yaitu di dua pasar, pasar Rancah dan pasar Rajadesa. Pasar Rancah dan pasar Rajadesa beroperasi setiap hari pada pukul 06.00 sampai 15.00. Selain itu benih ikan lele dari daerah ini juga dipasarkan ke beberapa daerah lainnya seperti Bogor, Karawang, dan Jakarta. Permintaan pasar lokal dan pasar dari luar daerah yang belum tercukupi, memperlihatkan adanya peluang peningkatan permintaan akan benih ikan lele di masa yang akan datang.

Berhasil tidaknya suatu usahatani sangat ditentukan oleh sistem pemasaran dan panjangnya saluran pemasaran yang digunakan. Banyaknya lembaga pemasaran yang terlibat dalam pemasaran benih ikan lele akan berpengaruh terhadap besarnya biaya pemasaran. Menurut Mursid (1993), banyaknya Lembaga pemasaran yang terlibat dalam penyaluran barang dalam saluran pemasaran akan berpengaruh terhadap tingginya biaya pemasaran. Hal ini akan menyebabkan harga suatu produk menjadi mahal sampai ke konsumen atau keuntungan produsen akan kecil.
Semakin banyak permintaan ikan lele dipasar, mengakibatkan adanya persaingan yang ketat dalam berproduksi maupun pemasarannya yang dibeli oleh para konsumen. Salah satu cara untuk dapat memperluas pasar yaitu dengan mengefektifkan pemasaran yang efisien dan memperlancar arus barang dari produsen ke konsumen. Melalui efisiensi pemasaran ini, harga benih ikan lele akan meningkat dan akhirnya akan meningkatkan keuntungan pembudidaya benih ikan lele dan lembaga pemasaran yang terlibat.

Berdasarkan uraian diatas, maka perlu dilakukan penelitian dengan judul Analisis Efisiensi dan Saluran Pemasaran benih Ikan Lele di Desa Situmandala Kecamatan Rancah Kabupaten Ciamis

\section{METODE PENELITIAN}

Penelitian ini termasuk dalam penelitian deskriptif dengan menggunakan metode survei. Pengambilan data primer di peroleh dengan cara melakukan wawancara langsung terhadap petani ikan lele dan pedagang perantara dengan menggunakan daftar pertanyaan (kuesioner) yang telah di siapkan. Data sekunder di peroleh dari dinas atau instansi terkait dan studi literatur yang ada kaitannya dengan penelitian yang dilakukan (Dinas Pertanian, UPP, BPS, Kantor Desa dan lain-lain). 
Gambaran tentang saluran pemasaran yang di lakukan oleh tiap lembaga pemasaran dilakukan secara deskriptif. Sedangkan untuk menganalisis besarnya marjin pemasaran, keuntungan yang diperoleh pedagang pelantara dan besarnya persentase bagian harga yang di terima oleh petani produsen di gunakan rumusan sebagai berikut (Limbong dan Sitorus, 1987) :

\section{Marjin Pemasaran}

Marjin pemasaran adalah perbedaan harga antara pembayaran konsumen dengan harga yang diterima oleh Pembudidaya Benih Ikan Lele di Desa Situmandala Kecamatan Rancah.

Rumus yang digunakan sebagai berikut :

Keterangan :

$$
\text { Mi }=\text { Psi }-\mathbf{P b i}
$$

$\mathrm{Mi}=$ Marjin pemasaran di tingkat ke-i

Psi $=$ Harga jual di tingkat ke-i

Pbi $=$ Harga beli di tingkat ke-i

2. Keuntungan Pedagang Perantara

Rumus yang digunakan :

$\mathbf{K p}=\mathbf{M p}-\mathbf{B p}$

Keterangan :

$\mathrm{Kp}=$ Keuntungan pemasaran di tingkat ke $\mathrm{i}$

$\mathrm{Mp}=$ Marjin Pemasaran di tingkat kr i

$\mathrm{Bp}=$ Biaya pemasaran di tingkat ke $\mathrm{i}$

3. Persentase Harga yang di terima Petani (Farmer's Share)

$$
\text { Farmer's share adalah }
$$

perbandingan antara harga yang diterima
Pembudidaya Benih Ikan Lele dengan harga yang dibayarkan oleh konsumen akhir dan dinyatakan dalam bentuk persentase.

Untuk mengetahui bagian yang diterima petani (pembudidaya) dari harga ditingkat pengecer, rumus yang digunakan sebagai berikut:

$$
F s=\frac{H p}{H e} \times 100 \% \quad \text { Keterangan: }
$$

Fs : Farmer's Share (bagian yang diterima Pembudidaya)

Hp : Harga Jual Ditingkat Pembudidaya $(\mathrm{Rp} / \mathrm{Kg})$

He : Harga Ditingkat Pedagang Pengecer $(\mathrm{Rp} / \mathrm{Kg})$

\section{HASIL DAN PEMBAHASAN}

\section{Saluran Pemasaran Benih Ikan Lele}

Saluran pemasaran merupakan jembatan antara petani produsen dengan konsumen akhir yang melalui berbagai tingkatan lembaga pemasaran. Saluran pemasaran yang dilalui sangat berpengaruh terhadap keuntungan yang di terima oleh masing-masing lembaga pemasaran yang terlibat dalam menyalurkan benih ikan lele. Lembaga yang terlibat dalam pemasaran benih ikan lele di Desa Situmandala sampai ke konsumen akhir adalah pedagang pengepul, pedagang besar dan pedagang pengecer, berdasarkan hasil penelitian ternyata terdapat dua saluran pemasaran 
benih ikan lele dari Desa Situmandala seperti terlihat pada Gambar 2.

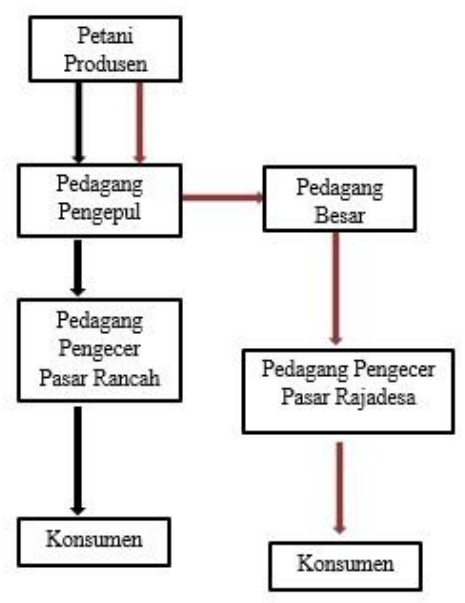

Keterangan:

: Saluran Pemasaran I

: Saluran Pemasaran II

Gambar 2. Saluran Pemasaran Benih Ikan Lele dari Desa Situmandala

\section{Kegiatan di Tingkat Petani Responden}

Karman (1999) menyatakan bahwa petani adalah seseorang yang sebagian besar hanya menguasai pekerjaan budidaya untuk menghasilkan produk primer. Para petani produsen benih ikan lele di Desa Situmandala memiliki sekala usaha yang berbeda sehingga hasil usahatani nya pun berbeda, ada yang banyak ada pula yang sedikit. Produksi benih ikan lele yang di hasilkan oleh petani di jual ke pedagang pengepul yang masih berada di Desa Situmandala. Cara pembayaran yang dilakukan oleh pedagang pengepul kepada petani yang menjual hasil produksinya yaitu secara tunai.
Biaya pemasaran adalah sejumlah biaya yang di keluarkan dalam proses pemasaran. Adapun biaya yang dikeluarkan oleh petani produsen untuk mengalirkan produksi benih ikan lele ke pedagang pengepul adalah hanya biaya tenaga kerja dalam proses pemanenan dengan rata-rata biaya yang di keluarkan Rp. 1,20 per ekor benih ikan lele.

\section{Kegiatan di Tingkat Pedagang \\ Pengepul}

Pedagang pengepul adalah pedagang yang membeli produk pertanian dari petani produsen yang di kumpulkan pada suatu tempat kemuadian produk tersebut dijual kembali ke pedagang lain.

Cara pembelian benih ikan lele yang i lakukan oleh pedagang pengepul dari petani yaituh dengan cara per ekor dengan harga rata-rata Rp.150 per ekor benih ikan lele dan di bayar dengan cara tunai. Penjualan yang di lakukan oleh pedagang pengepul ada dua cara, yaitu dijual langsung kepada pedagang pengecer di pasar rancah dengan harga rata-rata Rp.285 per ekor dan apabila produksi melimpah, produk benih ikan lele dijual kepada pedagang besar di Kecamatan Rancah dengan harga Rp.170 per ekor, pedagang besar yang mengambil kepada tempat 
pedagang pengepul sehingga biaya bongkar muat, pengangkutan dan transportasi ditanggung pedagang besar. penyusutan. Untuk lebih jelasnya dapat di

Biaya-biaya yang dikeluarkan oleh lihat pada tabel 11 .

pedagang pengepul dalam proses

pemasaran benih ikan lele yaitu biaya

Tabel 11. Rata-rata Biaya Pemasaran Benih Ikan Lele di Tingkat Pedagang Pengepul.

\begin{tabular}{|c|c|c|c|c|c|}
\hline \multirow{3}{*}{ No } & \multirow{3}{*}{ Jenis Biaya } & \multicolumn{4}{|c|}{ Besarnya Biaya Pemasaran } \\
\hline & & \multicolumn{2}{|c|}{$\begin{array}{c}\text { Saluran I } \\
\text { Ke Pasar Rancah }\end{array}$} & \multicolumn{2}{|c|}{$\begin{array}{c}\text { Saluran II } \\
\text { Ke Pedagang Besar }\end{array}$} \\
\hline & & Rp/ekor & $\%$ & Rp/ekor & $\%$ \\
\hline 1 & Pengangkutan & Rp. 0,5205 & 9,22 & - & - \\
\hline 2 & Bongkar Muat & Rp. 0,625 & 11,07 & Rp. 0,2035 & 4,33 \\
\hline 3 & Penyusutan & Rp. 4,5 & 79,71 & Rp. 4,5 & 95,67 \\
\hline & Jumlah & Rp. 5,6455 & 100 & Rp.4,7035 & 100 \\
\hline
\end{tabular}

Sumber: Analisis Data Primer Tahun 2020

Tabel 11 menunjukan biaya terbesar yang di keluarkan oleh pedagang pengepul adalah biaya penyusutan yaituh Rp. 4,5 per ekor sekitar 79,71 persen untuk saluran pemasaran I dan 95,67 persen untuk saluran pemasaran II dari jumlah biaya yang di keluarkannya.

\section{Kegiatan di Tingkat Pedagang Besar}

Pedagang besar adalah pedagang yang membeli produk benih ikan lele dalam jumlah banyak yang umumnya berasal dari pedagang pengepul dan di jual kembali ke pedagang pengecer. Pedagang besar

membeli benih ikan lele dari pedagang pengepul dengan harga Rp 170 per ekor dan di jual ke pedagang pengecer dengan harga Rp. 240 per ekor yang dibayar secara tunai.

Perlakuan yang dilakukan oleh pedagang besar benih ikan lele yaituh perlakuan pengangkutan dan penyimpanan. Proses perlakuan berkaitan dengan besarnya biaya yang di keluarkan oleh pedagang besar benih ikan lele tersebut. Jenis dan besarnya biaya yang di keluarkan oleh pedagang besar dapat di lihat pada Tabel 12. 
Tabel 12 Rata-rata Biaya Pemasaran Benih Ikan Lele di Tingkat Pedagang Besar

\begin{tabular}{rlccc}
\hline \multirow{2}{*}{ No } & & \multicolumn{1}{c}{ Jenis Biaya } & \multicolumn{2}{c}{ Besarnya Biaya } \\
\cline { 3 - 4 } & & Biaya Pengangkutan & 0,11 & R \\
\hline & Biaya Bongkar Muat & 0,1 & 2,10 \\
3 & Biaya penyusutan & 4,94 & 1,90 \\
4 & Biaya Lain-lain & 0,1 & 94,10 \\
\multicolumn{2}{r}{ Jumlah } & 5,25 & 1,90 \\
\hline
\end{tabular}

Sumber: Analisis Data Primer Tahun 2020

Tabel 12 menunjukan bahwa jenis biaya yang paling besar adalah biaya penyusutan yaitu Rp. 4,94 per ekor atau 94,10 persen dari total biaya yang di keluarkannya.

\section{Kegiatan di Tingkat Pedagang Pengecer}

Benih ikan lele dari pedagang besar di salurkan kepada pedagang pengecer akhirnya sampai ke tangan konsumen. Pedagang pengecer benih ikan lele dalam penelitian ini ada 2 tempat, yaitu:

1. Pedagang Pengecer di Pasar Rancah Pedagang pengecer di pasar Rancah ini cara mendapatkan benih ikan lele yitu dari pedagang pengepul desa yang datang secara rutin. mereka membeli benih ikan lele dari pedagang pengepul dengan harga
Rp.230 per ekor dan di jual dengan harga rata-rata Rp.285 per ekor dan pembayaran secara tunai.

2. Pedagang Pengecer di pasar Rajadesa

Pedagang pengecer yang ada di pasar Rajadesa membeli benih ikan lele dari pedagang besar rancah yang secara rutin mengirimnya dengan harga Rp.240 per ekor dengan cara membayar secara tunai. Sedangkan harga jual ke konsumen rata-rata Rp.290 per ekor. Besarnya biaya pemasaran antara pedagang pengecer di pasar Rancah dengan pedagang pengecer di pasar Rajadesa dapat di lihat pada Tabel 13. 
Tabel 13. Rata-rata Biaya Pemasaran Benih Ikan Lele di Tingkat Pedagang Pengecer Yang Ada di Pasar Rancah Dan di pasar Rajadesa.

\begin{tabular}{cccccc}
\hline \multirow{2}{*}{ No } & \multirow{2}{*}{ Jenis Biaya } & \multicolumn{2}{c}{ Biaya Pemasaran di Pasar Rancah } & \multicolumn{2}{c}{ Biaya Pemasaran di Pasar Rajadesa } \\
\cline { 3 - 6 } & & Rp/Ekor & $\%$ & Rp/Ekor & $\%$ \\
\hline 1 & Upah Kerja & 10,5 & 42,17 & 7,24 & 35,09 \\
2 & Penyustan & 6,9 & 27,71 & 7,19 & 34,84 \\
3 & Retribusi & 7,5 & 30,12 & 6,205 & 30,07 \\
\hline & Jumlah & 24,9 & 100 & 20,635 & 100
\end{tabular}

Sumber: Analisis Data Primer Tahun 2020

Berdasarkan tabel di atas dapat di ketahui bahwa biaya yang paling besar yang di keluarkan oleh pedagang pengecer di pasar Rancah dan di pasar Rajadesa adalah biaya upah kerja yaitu Rp. 10,5 per ekor atau 42,17 persen dan Rp. 7,24 per ekor atau 35,09 persen.

6. Analisis Marji, Biaya dan

\section{Keuntungan Pemasaran Antar}

\section{Lembaga Pemasaran.}

Perlakuan-perlakuan

yang

dilakukan oleh lembaga pemasaran dapat mempengaruhi besarnya biaya yang harus dikeluarkan oleh setiap lembaga pemasaran serta berpengaruh pula terhadap besarnya marjin dan keuntungan pemasaran. Besarnya biaya berpengaruh juga terhadap penentuan harga produk, sedangkan harga prodak berpengaruh terhadap besar kecilnya nilai farmer's share. Untuk lebih jelasnya besarnya marjin, biaya dan keuntungan lembaga pemasaran dapat di lihat pada Tabel 14. 


\begin{tabular}{|c|c|c|c|}
\hline No & Lembaga Pemasaran & Saluran I & Saluran II \\
\hline 1 & Petani & & \\
\hline & - Harga Jual & Rp. 150 / ekor & Rp.150 / ekor \\
\hline \multirow[t]{6}{*}{2} & Pedagang Pengepul & & \\
\hline & - Harga Beli & Rp.150 / ekor & Rp.150/ekor \\
\hline & - $\quad$ Harga Jual & Rp.230 / ekor & Rp.170/ekor \\
\hline & Biaya & Rp.5,6455 / ekor & Rp.4,7035/ekor \\
\hline & - Keuntungan & Rp.74,354 / ekor & Rp.15,2965/ekor \\
\hline & - Marjin & Rp.80 / ekor & Rp.20/ekor \\
\hline \multirow[t]{6}{*}{3} & Pedagang Besar & & \\
\hline & - Harga Beli & - & Rp.170/ekor \\
\hline & - $\quad$ Harga Jual & - & Rp.240/ekor \\
\hline & - Biaya & - & Rp.5,25/ekor \\
\hline & Keuntungan & - & Rp.64,75/ekor \\
\hline & Marjin & - & Rp.70/ekor \\
\hline \multirow[t]{6}{*}{4} & Pedagang Pengecer & & \\
\hline & - Harga Beli & Rp. 230/ekor & Rp.240/ekor \\
\hline & Harga Jual & Rp. 285/ekor & Rp.290/ekor \\
\hline & Biaya & Rp. 24,9/ekor & Rp.20,635/ekor \\
\hline & Keuntungan & Rp. 30,1/ekor & Rp.29,365/ekor \\
\hline & - Marjin & Rp. 55/ekor & Rp.50/ekor \\
\hline \multirow[t]{4}{*}{5} & Total & & \\
\hline & Biaya & Rp.30,5455/ekor & Rp.30,5885/ekor \\
\hline & - Keuntungan & Rp.104,454/ekor & Rp.109,4115/ekor \\
\hline & - Marjin & Rp.135/ekor & Rp.140/ekor \\
\hline
\end{tabular}

Tabel 14. Rata-rata Biaya, Marjin dan Keuntungan Pemasaran Benih Ikan Lele Pada Saluran Pemasaran I dan II di Daerah Peneliian Tahun 2020

Sumber: Analisis Data Primer Tahun 2020

Tabel 14 menunjukan bahwa pada saluran Para pelaku pemasaran ternyata pemasaran I besarnya marjin pemasaran adalah Rp.135 per ekor, biaya pemasaran Rp.30,5455 per ekor, dan keuntungan Rp.104,454 per ekor. Marjin, biaya dan keuntungan terbesar perada pada pedagang pengepul. Saluran pemasaran II besarnya marjin pemasaran adalah Rp.140 per ekor, biaya pemasaran Rp.30,5885 per ekor dan keuntungan pemasaran Rp.109,4115 per ekor. Marjin, biaya dan keuntungan terbesar berada pada pedagang besar. pada proses pengaliran produknya memerlukan biaya-biaya yang berbedabeda. Saluran pemasaran I yang hanya melibatkan dua lembaga tataniaga,yang paling besar mengeluarkan biaya adalah pedagang pengecer Rp. 24,9 per ekor, sedangkan pedagang pengepul mengeluarkan biaya Rp.5,6455 per ekor. Marjin pemasaran di pedagang pengepul pada saluran pemasaran I yaitu Rp.80 per 
ekor dan di pedagang pengecer Rp. 55 per ekor.

Besarnya biaya pemasaran di pedagang pengepul pada saluran pemasara II Rp.4,7035 per ekor,di pedagang besar Rp.5,25 per ekor dan di pedagang pengecer Rp.20,635 per ekor.

\section{Distribsi Marjin Pemasaran}

Pada saluran pemasaran I keuntungan yang paling besar di terima oleh pedagang pengepul sebesar 71,19 persen karena mengeluarkan biaya pemasaran lebih sedikit dan menjual benih ikan lele dengan harga lebih tinggi sehingga keuntungan yang di peroleh lebih tinggi pula dibandingkan dengan lembaga pemasaran yang lain. Sedangkan pada saluran pemasaran II keuntungan paling besar di terima oleh pedagang besar yang mencapai 59,18 persen. Dengan demikian dapat disimpulkan bahwa yang mempengaruhi marjin pemasaran adalah panjang pendeknya saluran pemasaran, semakin panjang saluran pemasaran akan semakin besar marjinnya. Oleh karena itu harga di tingkat konsumen akan lebih tinggi jika saluran pemasaran semakin panjang.

8. Farmer's share atau Persentase Bagian Harga yang Diterima Petani

Farmer,s Share adalah perbandingan harga yang diterima produsen dengan harga yang dibayarkan oleh konsumen yang dinyatakan dalam persen. Berdasarkan hasil penelitian di lapangan menunjukan bahwa harga jual di petani pada saluran pemasaran I yaitu Rp. 150 per ekor, dan harga di pedagang pengecer Rp. 285 per ekor, maka dalam saluran pemasaran I ini besarnya nilai Farmer's share adalah:

$$
\mathrm{FS}=\frac{\mathrm{Hp}}{\mathrm{He}} \times 100 \%
$$

$$
\begin{aligned}
& \mathrm{FS}=\frac{\text { Rp. } 150}{\text { Rp. } 285} \mathrm{X} 100 \% \\
& =52,631 \%
\end{aligned}
$$

Saluran pemasaran II harga di tingkat petani yaitu Rp. 150 per ekor dan di pedagang pengecer Rp. 290 per ekor. Besarnya Farmer's Share pada saluran II adalah:

$$
\mathrm{FS}=\frac{\mathrm{Hp}}{\mathrm{He}} \times 100 \%
$$

$$
\mathrm{FS}=\frac{\text { Rp. } 150}{\text { Rp. } 290} \times 100 \%
$$

$$
=51,724 \%
$$


Dari hasil perhitungan di ketahui bahwa nilai Farmer's Share pada saluran I sebesar 52,631 persen dan saluran II sebesar 51,724 persen, sehingga persentase bagian harga yang diterima oleh petani (Farmer's Share) pada saluran I lebih besar dari pada saluran II.

\section{Analisis Perbandingan Farmer's Share dan Marjin Pemasaran Benih Ikan Lele}

Tabel 15. Analisis Perbandingan Farmer's Share dan Marjin Pemasaran Benih Ikan Lele

\begin{tabular}{lccc}
\hline Saluran Pemasaran & Farmer's Share \% & Marjin \% & Keterangan \\
\hline Saluran Pemasaran I & 52,631 & 47,368 & FS > MP \\
Salran Pemasaran II & 51,724 & 48,275 & FS > MP \\
\hline
\end{tabular}

Sumber : Analisis Data Primer, 2020

Berdasarkan tabel di atas bila dilihat dari perbandingan nilai total Marjin Pemasaran dan Farmer's Share maka seluruh saluran pemasaran benih ikan lele yang ada di Desa Situmandala sudah efisien, namun saluran pemasaran I merupakan saluran pemasaran yang lebih efisien dibandingkan dengan saluran pemasaran II. Namun saluran pemasaran II ini yang menjadi pilihan utama pembudidaya.

Penyebab petani benih ikan lele lebih memilih menjual hasil produksinya melalui saluran pemasaran II dibandingkan dengan melalui saluran pemasaran I, walapun harga beli saluran pemasaran I dan II cenderung sama, hal itu di karenakan saluran pemasaran II lebih kontinyu dan menerima hasil produksi dalam jumlah yang banyak sedangkan saluran pemasaran I menerima hasil produksi hanya dalam jumlah yang sedikit.

\section{KESIMPULAN DAN SARAN}

\section{Kesimpulan}

Berdasarkan hasil penelitian dan pembahasan, maka dapat di ambil kesimpulan sebagai berikut : 
1. Terdapat dua saluran pemasaran benih ikan lele di Desa Situmandala yaitu :

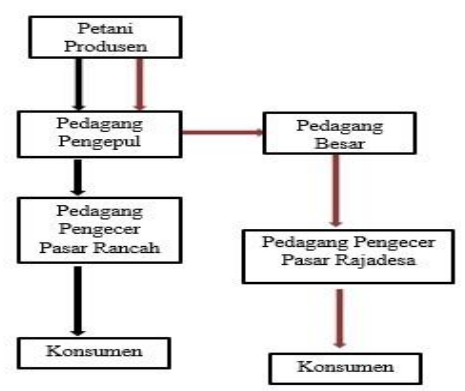

Keterangan:

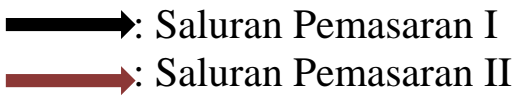

2. Besarnya biaya pemasaran benih ikan lele pada saluran pemasaran I yaitu di pedagang pengepul sebesar Rp.80 per ekor dan pada pedagang pengecer sebesar Rp. 55 per ekor. Pada saluran pemasaran II besarnya marjin di pedagang pengepul sebesar Rp.20 per ekor, di pedagang besar Rp.70 per ekor dan pada pedagang pengecer sebesar Rp.50 per ekor.

3. Persentase bagian harga yang di terima oleh petani pada saluran pemasaran I sebesar 52,631 persen dan pada saluran pemasaran II sebesar 51,724 persen dari bagian harga yang dibayarkan oleh konsumen.

4. Berdasarkan hasil penelitian, dilihat dari perbandingan marjin dan farmer's sehare maka seluruh saluran pemasaran benih ikan lele yang ada di Desa Situmandala sudah efisien, namun saluran pemasaran I merupakan saluran pemasaran yang lebih efisien dibandingkan dengan saluran pemasaran II. Namun saluran pemasaran II ini yang menjadi pilihan utama pembudidaya.

\section{Saran}

1. Petani harus lebih aktif mencari peluang pasar yang lebih dekat dengan lokasi produsen (petani benih ikan lele), dan mencari konsumen (petani pembesaran ikan lele) yang lebih kontinyu dalam menerima produk, agar resiko biaya transpot, resiko penyusutan produk dapat di tekan serendah mungkin dan kestabilan harga dapat terus di pertahankan sehingga keuntungan pemasaran dapat meningkat.

2. Dalam pelaksanaan panen harus di laksanakan secara tepat yaitu waktu benih ikan lele berukuran $5-7 \mathrm{~cm}$ atau sesuai dengan kebutuhan pasar agar kualitas benih ikan lele yang dihasilkan akan tetap baik.

3. Untuk meningkatkan kualitas benih ikan lele, pembudidaya disarankan menggunakan induk ikan lele yang bersertifikat dan menggunakan metode budidaya yang baik dan benar sehingga dapat meningkatkan hasil produksi 
yang dapat menambah kentungan bagi petani.

\section{DAFTAR PUSTAKA}

Hanafi, AM dan Saefudin (2014). Pembangunan Wilayah Sektor Perikanan, Jakarta : Universitas Indonesia (UI).

Kementrian Kelautan dan Perikanan (2013). Klasifikasi Jenis Perikanan Air Laut, Air Payau dan Air Darat.
Limbong, W.H. dan Sitorus, P. 1987. Pengantar Tataniaga Pertanian. Jurusan Ilmi-Ilmu Sosial Ekonomi Pertanian. Fakultas Pertanian InstitutPertanian Bogor. Bogor.

Murshid, 1993. Manajemen Pemasaran. Bina Aksara. Jakarta.

Suyanto R, 1999. Budidaya Ikan Lele. Jakarta : Penebar Swadaya. 